\title{
DECISION SUPPORT SYSTEM FOR DETERMINING APPROPRIATE FRANCHISE LOCATIONS USING THE PROFILE MATCHING METHOD
}

\author{
Tati Mardiana ${ }^{1}$, Yesni Malau ${ }^{2}$ \\ Information Technology ${ }^{1}$; Electrical Engineering ${ }^{2}$ \\ Universitas Bina Sarana Informatika ${ }^{1,2}$ \\ http://www.bsi.ac.id 1,2 \\ E-mail: tati.ttm@bsi.ac.id, yesni.ymu@bsi.ac.id
}

\begin{abstract}
Abstrak
Menemukan lokasi yang tepat sangat penting saat memulai waralaba, lokasi yang tepat akan mempengaruhi risiko bisnis dan profitabilitas waralaba secara keseluruhan. Namun demikian, ada beberapa waralaba yang mengalami kebangkrutan dalam menjalankan usahanya dimana salah satu faktor penyebab bangkrutnya bisnis waralaba adalah lokasi yang tidak memenuhi beberapa kriteria yang mendukung kesuksesan bisnis. Oleh karena itu, tujuan dari penelitian ini adalah mengusulkan model sistem pendukung keputusan untuk menentukan lokasi waralaba berdasarkan kesesuaian profil antara nilai data aktual suatu lokasi dengan nilai profil lokasi yang diharapkan oleh pemilik waralaba. Metode profile matching memiliki tingkat objektivitas yang lebih baik karena mengukur nilai setiap variabel indikator. Pada penelitian ini kriteria penentuan lokasi waralaba adalah calon pelanggan, akses ke lokasi, kompetisi, dan tempat. Hasil pengujian menunjukkan bahwa sistem pendukung keputusan penentuan lokasi waralaba dengan metode profile matching memenuhi persyaratan fungsional sehingga sistem pendukung keputusan ini membantu pemilik waralaba untuk menentukan lokasi yang tepat saat memulai sebuah usaha waralaba.
\end{abstract}

Kata Kunci: Lokasi, Waralaba, Metode Profile Matching, Sistem Pendukung Keputusan.

\begin{abstract}
Finding the appropriate location is crucial when starting a franchise. The appropriate location will affect the overall business risk and profitability of the franchise. Nevertheless, some franchises have a bankruptcy in running their business. One of the factors that contribute to the bankruptcy of a franchise business is a location that does not meet several criteria that support business success. Therefore, this study aims to propose a decision support system model to determine the location of the franchise based on matching profiles between the actual data value of a location and the value of the location profile expected by the franchisor. The profile matching method has a better level of objectivity because it measures the value of each indicator variable. The criteria for determining the location of a franchise are potential customers, access to location, competition, and costs. The test results show that the decision support system to determine the location of the franchise using the profile matching method meets the functional requirements. This decision support system helps franchises to determine the appropriate when starting a franchise.
\end{abstract}

Keywords: Location, Franchise, Profile Matching Method, Decision Support System.

\section{INTRODUCTION}

In recent years, franchising in several developed countries has grown significantly. Data from the International Franchise Association reports that in 2015 there were around 780 thousand franchises in the world. Moreover, the franchise has an impact on the opening of around 8.9 million jobs. Meantime, data from the 2013 World Franchise Council Meeting shows that the number of franchises in three ASEAN countries
(Malaysia, the Philippines, and Singapore) has reached 2.52 thousand franchises. In Indonesia, there are 698 active franchises with 24.4 thousand outlets consisting of $63 \%$ local franchises, and $37 \%$ foreign franchises so that the turnover reaches 172 trillion rupiahs (Febrianty \& Fatmariani, 2018). With franchising, anyone can become a successful entrepreneur without having to establish a business from scratch. The franchise also facilitates an effective management system and has clear prospects and excellent stability for 
budding entrepreneurs. However, the failure rates for both are very striking, typically ranging from $50 \%-60 \%$ of local franchises and only $2 \%-3 \%$ of foreign franchises. One of the contributing factors that usually cause a franchise to fail to represent the location selected does not fulfill several key criteria to support business success (Imanuwelita, Putri, \& Amalia, 2018).

Determining the appropriate location is crucial when starting a franchise as this will affect fixed costs and variable costs, both in the medium and extended-term. Consequently, it has an impact on potential benefits and business risks (Fu'ad, 2015). A prospective franchisee typically requires several crucial factors accurately to determine the appropriate franchise location. Ordinarily, prospective franchises properly consult the franchisor to determine the appropriate location. Notwithstanding, the appropriate location is uneasy to determine accurately ( $\mathrm{P}$, Sihwi, \& Anggraningsih, 2014) because each alternative location typically maintains various characteristics.

There have been several previous studies that have implemented various algorithms to determine franchise locations. Khumaidi in his study uses Case-Based Reasoning (CBR) and the Nearest Neighbor algorithm to determine the prospects for franchise locations. This study compares the experimental cases with the most similar case data. This research shows that the average time required to determine the appropriate location of a franchise takes place 1.15 minutes with an accuracy rate of 95\% (Khumaidi, 2016). Next, Welda et al used the scoring system method to produce a range of franchise location categorizations, namely less feasible, feasible, and very feasible (Welda, Kusuma, \& Mubaraq, 2017). Meantime, Nuhayati et al used Naïve Bayes to determine strategic and non-strategic locations for culinary businesses (Nuhayati, Dedih, \& Mulyana, 2017). Furthermore, Imanuwelita et al using the AHP and Vikor methods to determine the location of the franchise are feasible or not feasible. Based on the test performance, the most excellent accuracy is $85 \%$ with a threshold value of 0.56(Imanuwelita et al., 2018).

Therefore, we aim to determine the priority level of the franchise location using the profile matching method. The profile matching process is generally comparing the factual data of a with the ideal so that we can the in (GAP). The smaller the resulting gap, the greater the weight of the value, which means that it obtains a grander chance of being elected (Verdian \& Wantoro, 2019). The profile matching method can provide recommendations for selecting locations close to the ideal profile. Although no franchise location is the same as the needs of potential franchise recipients (Efendi, 2019).

\section{RESEARCH METHOD}

\section{Type of Research}

By the aim, this type of research is research and development. Research and development is a research approach used to produce certain products well and evaluate the effectiveness of these products (Danang \& Nisar, 2017). This study will apply the profile matching method to the decision support system for selecting franchise locations.

\section{Time and Place of Research}

We properly researched for three months from September to December 2020. The research location was a food franchise in Depok City by reason it represented a modern city of services and trade.

\section{Research Target / Subject}

The target or research subject is the franchisee in Depok City, West Java Province who will determine a location for their franchise. To obtain this data, we conducted a field study on the location of the franchise.

Data, Instruments, and Data Collection Technique

This study uses data sources, as follows:

\section{Primary Data}

Primary data obtained directly from franchisees.

2. Secondary data

Secondary data collected from literature studies, journals, reports, and others related to determining the appropriate business location.

The techniques for collecting primary and secondary data are as follows:

1. Observation

Direct and detailed observation of the franchise to find information about the conditions of the franchise location.

2. Interview

Interviews with franchise recipients about the criteria, how to determine the location of the franchise, problems in determining the franchise location, and confirm the results of data obtained from observations.

3. Literature study

Collecting literature, data, good information from scientific journals, books, websites, and 
magazines regarding information about determining the appropriate franchise location.

\section{Research Procedure}

follows:

The steps in this research process are as

1. Preliminary Study

Reviewed several related works of literature to obtain an overview of the problems in determining business locations, franchises, and profile matching methods. Furthermore, we conduct field studies to gain an overview of franchise prospects, the franchise system and identify problems related to business locations. The results of the preliminary studies become input for the development of a decision support system for determining a franchise location.

2. Analysis System Requirement

Collecting information such as functional and non-functional requirements for the construction of a decision support system for determining business locations for franchises. Functional requirements that typically contain any processes contained in the system. Meanwhile, nonfunctional requirements are those that emphasize the behavioral properties of the system.

3. Design

Designing a database and program flow according to the needs of a decision support system for determining the franchise location.

4. Implementation

Implement designs into program code to produce an appropriate siting decision support system.

\section{Evaluation}

Reviewing the results of testing the decision support system for determining the right franchise location and providing recommendations to franchisees when opening or expanding franchise business.

\section{Data Analysis Technique}

We analyzed the data to obtain information on the functional and non-functional requirements of a decision support system for determining the franchise location. The decisionmaking model in this study uses the profile matching method to determine the alternative rankings of the franchise location. The following steps according to the Matching Profile method (Dhammayanti, Wicaksana, \& Hansun, 2019) are :

\section{Weighting}

Determine the weight of the gap on each criterion according to the gap value. Table 1 describes the weight of the gap value. The gap value represents a difference between the profile of each alternative and the target profile. To calculate the gap value for each criterion following the formula:

$$
\text { Gap = test data profile }- \text { target profile .. (1) }
$$

Table 1. Weight GAP Value

\begin{tabular}{ccl}
$\begin{array}{c}\text { Gap } \\
\text { Value }\end{array}$ & $\begin{array}{c}\text { Value } \\
\text { Weight }\end{array}$ & \multicolumn{1}{c}{ Description } \\
\hline 0 & 5 & $\begin{array}{l}\text { Not GAP (competence as } \\
\text { required) }\end{array}$ \\
\hline 1 & 4,5 & Feasibility excess 1 level \\
\hline-1 & 4 & Feasibility shortage 1 level \\
\hline 2 & 3,5 & Feasibility excess 2 level \\
\hline-2 & 3 & Feasibility shortage 2 level \\
\hline 3 & 2,5 & Feasibility excess 3 level \\
\hline-3 & 2 & Feasibility shortage 3 level \\
\hline 4 & 1,5 & Feasibility excess 4 level \\
\hline-4 & 1 & Feasibility shortage 4 level \\
\hline
\end{tabular}

2. Counting and Grouping Core Factor and Secondary Factor

After determining the weight value of the gap for the required criteria, then classify the criteria from the franchise location into two groups namely core factors and secondary factors.

a. Core factor

Core factors are the most important or the primary criteria or most needed by an assessment that can obtain optimal results. To calculate the core factor following the formula:

$\mathrm{NCF}=\frac{\sum \mathrm{NC}}{\sum \mathrm{IC}}$

NCF: average value of core factor

NC: Number of the total core factor

IC: Number of the items core factor

b. Secondary factor

Secondary factors are criteria other than the criteria in the core factors. To calculate the core factor following the formula:

$\mathrm{NSF}=\frac{\sum \mathrm{NF}}{\sum \mathrm{IS}}$

NSF: average value of the secondary factor

NS: Number of a total secondary factor

IS: Number of items secondary factor

c. Calculating the Total Value of Each Criterion

To calculate the total value of each following the formula:

$\mathrm{Ni}=\mathrm{x} \cdot \mathrm{NCF}+\mathrm{y} \cdot \mathrm{NSF}$ 
NCF: Average core factor values.

NSF: Mean value of the secondary factor.

$\mathrm{Ni}$ : Total value of aspects.

$\mathrm{x}$ : The percentage value entered for the core factor. $\mathrm{y}$ : The percentage value entered for the second factor.

\section{Ranking}

The result of the profile matching process is a ranking of alternative franchise locations. To calculate the total value of each criterion following the formula:

Rangking $=(\mathrm{x}) \% \mathrm{~N} 1+(\mathrm{x}) \% \mathrm{~N} 2+\ldots+(\mathrm{x}) \% \mathrm{Nj}$

$\mathrm{x}$ : The percent value of the final result formula

N1: Total criteria value 1

N2: Total criteria value 2

$\mathrm{Nj}$ : Total criteria value $\mathrm{n}$

Furthermore, sorting the total value of the largest to the smallest value to get a ranking of each alternative franchise location.

\section{RESULT AND DISCUSSION}

\section{Requirement System Analysis}

The franchisee uses 4 aspect and 11 criteria in the process of determining the franchise location. Aspects and criteria for franchise locations are as follows:

1. Potential customers
a. Population density (C1)
b. Center of the crowd (C2)
c. Other businesses nearby (C3)

2. Competitors
a. Direct competitor (C4)
b. Indirect competitor (C5)

3. Access to location
a. Highway access (C6)
b. Pedestrian traffic (C7)
c. Vehicle traffic (C8)

4. Infrastructure
a. Parking area (C9)
b. Rental fee (C10)
c. Other supporting facilities (C11)

This study uses 10 samples of location data in the process of determining the right franchise location. We typically process the data by converting all the criteria values into a scale of 5 . We efficiently performed data analysis to determine location rankings for franchises using the profile matching method. Then, we analyze the franchise location data using the profile matching method with the following results:

\section{Mapping gap}

Determine the gaps for each criterion of the franchise location. The process of determining the gap is by calculating the difference between the franchise location profile and the target profile. Table 2 describes the results of the gap mapping.

Table 2. Mapping Gap

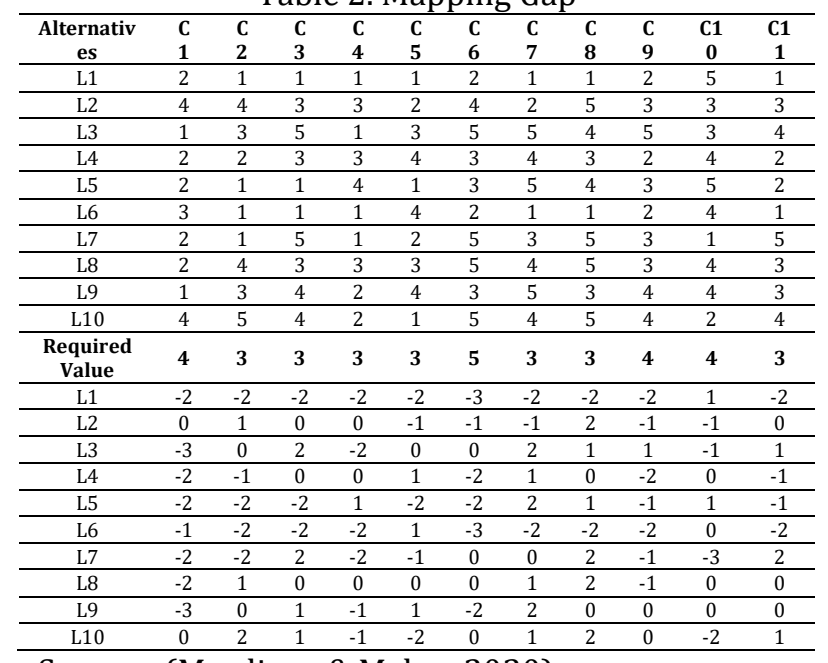

Source : (Mardiana \& Malau, 2020)

After obtaining the gap value, determine the gap weight value according to the gap weight value table. Table 3 describes the results of the weight gap value for each franchise location criterion.

Table 3. Results Weight Value of Gap

\begin{tabular}{cccccccccccc}
\hline Alternative & C1 & C2 & C3 & C4 & C5 & C6 & C7 & C8 & C9 & C10 & C11 \\
\hline L1 & 3 & 3 & 3 & 3 & 3 & 2 & 3 & 3 & 3 & 5 & 3 \\
\hline L2 & 5 & 5 & 5 & 5 & 4 & 4 & 4 & 4 & 4 & 4 & 5 \\
\hline L3 & 2 & 5 & 4 & 3 & 5 & 5 & 4 & 5 & 5 & 4 & 5 \\
\hline L4 & 3 & 4 & 5 & 5 & 5 & 3 & 5 & 5 & 3 & 5 & 4 \\
\hline L5 & 3 & 3 & 3 & 5 & 3 & 3 & 4 & 5 & 4 & 5 & 4 \\
\hline L6 & -1 & -2 & -2 & -2 & 1 & -3 & -2 & -2 & -2 & 0 & -2 \\
\hline L7 & -2 & -2 & 2 & -2 & -1 & 0 & 0 & 2 & -1 & -3 & 2 \\
\hline L8 & -2 & 1 & 0 & 0 & 0 & 0 & 1 & 2 & -1 & 0 & 0 \\
\hline L9 & -3 & 0 & 1 & -1 & 1 & -2 & 2 & 0 & 0 & 0 & 0 \\
\hline L10 & 0 & 2 & 1 & -1 & -2 & 0 & 1 & 2 & 0 & -2 & 1 \\
\hline
\end{tabular}

Source : (Mardiana \& Malau, 2020)

2. Counting and Grouping Core Factor and Secondary Factor

The franchisee classifies the criteria into two groups namely the core factor and the secondary factor. Also, they give weight to calculate the total value of the core factor and secondary factor. Table 4 describes the criteria, types, and weights of core factor and secondary factor.

Table 4. Criteria, Type, and Weights

\begin{tabular}{llc}
\hline \multicolumn{1}{c}{ Criteria } & \multicolumn{1}{c}{ Type } & $\begin{array}{c}\text { Weighting } \\
\text { NCF and SCF }\end{array}$ \\
\cline { 1 - 2 } Population density (C1) & Core factor & $80 \%$ \\
\cline { 1 - 2 } Center of the crowd (C2) & Core factor & \\
\cline { 1 - 2 } $\begin{array}{ll}\text { Other businesses nearby } \\
\text { (C3) }\end{array}$ & $\begin{array}{l}\text { Secondary } \\
\text { factor }\end{array}$ & \\
\hline
\end{tabular}


JURNAL RISET INFORMATIKA

Vol. 3, No. 1 December 2020
P-ISSN: 2656-1743 |E-ISSN: 2656-1735 DOI: https://doi.org/10.34288/jri.v3i1.180

\begin{tabular}{|c|c|c|}
\hline Criteria & Type & $\begin{array}{c}\text { Weighting } \\
\text { NCF and SCF }\end{array}$ \\
\hline Direct Competitor (C4) & Core factor & $60 \%$ \\
\hline Indirect Competitor (C5) & $\begin{array}{l}\text { Secondary } \\
\text { factor }\end{array}$ & $40 \%$ \\
\hline Highway access (C6) & Core factor & $70 \%$ \\
\hline Pedestrian traffic (C7) & Core factor & \\
\hline Vehicle traffic (C8) & $\begin{array}{l}\text { Secondary } \\
\text { factor }\end{array}$ & $30 \%$ \\
\hline Parking area (C9) & Core factor & $80 \%$ \\
\hline Rental fee (C10) & Core factor & \\
\hline $\begin{array}{l}\text { Other supporting facilities } \\
\text { (C11) }\end{array}$ & $\begin{array}{l}\text { Secondary } \\
\text { factor }\end{array}$ & $20 \%$ \\
\hline
\end{tabular}

Source : (Mardiana \& Malau, 2020)

The following process is to calculate the average core factor and secondary factor. The results of the calculation of the average core factor and secondary factor are as in table 5 .

Table 5. Average Value of Core Factor and Secondary Factor

\begin{tabular}{|c|c|c|c|c|c|c|c|c|}
\hline \multirow[t]{2}{*}{ Alternatives } & \multicolumn{2}{|c|}{$\begin{array}{c}\text { Prospective } \\
\text { customers }\end{array}$} & \multicolumn{2}{|c|}{ Competitor } & \multicolumn{2}{|c|}{$\begin{array}{l}\text { Access to } \\
\text { Location }\end{array}$} & \multicolumn{2}{|c|}{ Infrastructure } \\
\hline & NCF & NSF & NCF & NSF & NCF & NSF & NCF & NSF \\
\hline L1 & 3 & 3 & 3 & 3 & 2,5 & 3 & 3,75 & 3 \\
\hline L2 & 4,75 & 5 & 5 & 4 & 4 & 3,5 & 4 & 5 \\
\hline L3 & 3,5 & 3,5 & 3 & 5 & 4,25 & 4,5 & 4,25 & 4,5 \\
\hline L4 & 3,5 & 5 & 5 & 4,5 & 3,75 & 5 & 4 & 4 \\
\hline L5 & 3 & 3 & 4,5 & 3 & 3,25 & 4,5 & 4,25 & 4 \\
\hline L6 & 3,5 & 3 & 3 & 4,5 & 2,5 & 3 & 4 & 3 \\
\hline L7 & 3 & 3,5 & 3 & 4 & 5 & 3,5 & 3 & 3,5 \\
\hline L8 & 3,75 & 5 & 5 & 5 & 4,75 & 3,5 & 4,5 & 5 \\
\hline L9 & 3,5 & 4,5 & 4 & 4,5 & 3,25 & 5 & 5 & 5 \\
\hline L10 & 4,25 & 4,5 & 4 & 3 & 4,75 & 3,5 & 4 & 4,5 \\
\hline
\end{tabular}

Source : (Mardiana \& Malau, 2020)

From the calculation results of each of these criteria, then calculate the total value based on the percentage of the core factor and secondary factors that are likely to affect the performance of each profile.

Table 6. Total Value Gap

\begin{tabular}{crrrr} 
Tlternatives & \multicolumn{4}{c}{ Table 6. Total Value Gap } \\
\cline { 2 - 6 } & $\begin{array}{c}\text { Prospective } \\
\text { customers } \\
\text { (NT1) }\end{array}$ & $\begin{array}{c}\text { Competitor } \\
\text { (NT2) }\end{array}$ & $\begin{array}{c}\text { Access to } \\
\text { Location } \\
\text { (NT3) }\end{array}$ & $\begin{array}{c}\text { Infrastructure } \\
\text { (NT4) }\end{array}$ \\
\hline L1 & 3 & 3 & 2,7 & 3,6 \\
\hline L2 & 4,8 & 4,6 & 3,9 & 4,2 \\
\hline SL3 & 3,5 & 3,8 & 4,3 & 4,3 \\
\hline L4 & 3,8 & 4,8 & 4,1 & 4 \\
\hline L5 & 3 & 3,9 & 3,6 & 4,2 \\
\hline L6 & 3,4 & 3,6 & 2,7 & 3,8 \\
\hline L7 & 3,1 & 3,4 & 4,6 & 3,1 \\
\hline L8 & 4 & 5 & 4,4 & 4,6 \\
\hline L9 & 3,7 & 4,2 & 3,8 & 5 \\
\hline L10 & 4,3 & 3,6 & 4,4 & 4,1 \\
\hline
\end{tabular}

Source : (Mardiana \& Malau, 2020)

\section{Ranking}

Finally, sorting the total value of the largest to the smallest value to get a ranking of each alternative franchise location. The ranking results provide recommendations for franchise locations that are close to the ideal profile for franchising. Table 5 describes the ranking of franchise locations based on the results of calculations using the profile matching method.

Table 7. Ranking of The Franchise Location

\begin{tabular}{|c|c|c|c|c|c|c|}
\hline $\begin{array}{c}\text { Alternativ } \\
\text { es }\end{array}$ & $\begin{array}{l}\text { Prospecti } \\
\text { ve } \\
\text { customer } \\
\text { s }\end{array}$ & $\begin{array}{l}\text { Competit } \\
\text { or }\end{array}$ & $\begin{array}{l}\text { Access } \\
\text { to } \\
\text { Locatio } \\
\mathrm{n}\end{array}$ & $\begin{array}{l}\text { Infrastructu } \\
\text { re }\end{array}$ & $\begin{array}{c}\text { Tota } \\
\text { I } \\
\text { Valu } \\
\text { e }\end{array}$ & $\begin{array}{c}\text { Rankin } \\
\text { g }\end{array}$ \\
\hline & $35 \%$ & $20 \%$ & $30 \%$ & $15 \%$ & & \\
\hline L1 & 1,05 & 0,6 & 0,795 & 0,5625 & $\begin{array}{r}3,00 \\
8\end{array}$ & 10 \\
\hline L2 & 1,68 & 0,92 & 1,155 & 0,6 & $\begin{array}{r}4,35 \\
5 \\
\end{array}$ & 2 \\
\hline L3 & 1,225 & 0,76 & 1,2975 & 0,6375 & 3,92 & 6 \\
\hline L4 & 1,33 & 0,96 & 1,2375 & 0,6 & $\begin{array}{r}4,12 \\
8\end{array}$ & 4 \\
\hline L5 & 1,05 & 0,78 & 1,0875 & 0,6375 & $\begin{array}{r}3,55 \\
5 \\
\end{array}$ & 8 \\
\hline L6 & 1,19 & 0,72 & 0,795 & 0,6 & $\begin{array}{r}3,30 \\
5\end{array}$ & 9 \\
\hline L7 & 1,085 & 0,68 & 1,365 & 0,45 & 3,58 & 7 \\
\hline L8 & 1,4 & 1 & 1,3125 & 0,675 & $\mathrm{~s}$ & 1 \\
\hline L9 & 1,295 & 0,84 & 1,1325 & 0,75 & $\begin{array}{r}4,01 \\
8 \\
\end{array}$ & 5 \\
\hline L10 & 1,505 & 0,72 & 1,3125 & 0,6 & $\begin{array}{r}4,13 \\
8\end{array}$ & 3 \\
\hline
\end{tabular}

Source : (Mardiana \& Malau, 2020)

Based on the results of data analysis, functional and non-functional requirements for decision support systems for determining franchise locations as shown in Figure 1.

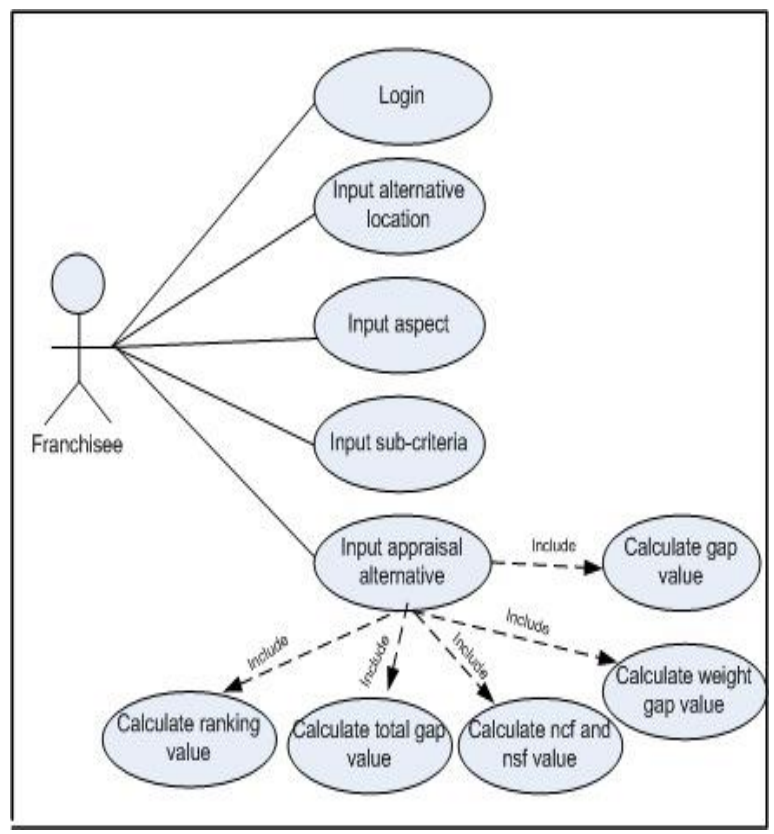

Source : (Mardiana \& Malau, 2020)

Figure 1. Uses Diagram The decision support system for determining franchise locations

\section{Software Design}

Figure 2 presents the mapping of entities that form a database. The results of the logical record structure transformation resulted in five tables, namely aspect, criteria, alternative location, result, and appraisal. 


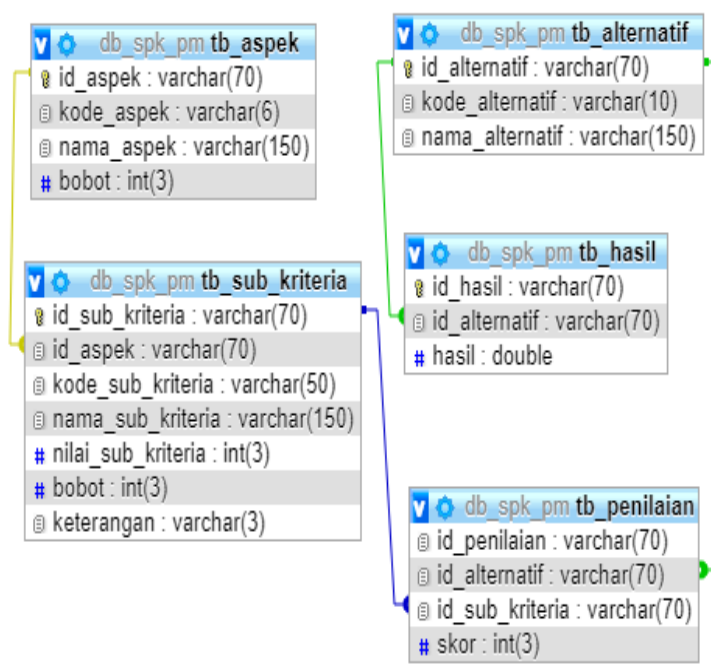

Source : (Mardiana \& Malau, 2020)

Figure 2 Database Design

The franchisee logs into the decision support system. Then, the franchisee inputs data on alternative locations and alternative assessments. After that, the system displays the output of the calculation of the gap value, the weight of the gap value, the NCF and SCF values, the total value, and the rating. Figure 3 describes the flow of determining the franchise location.

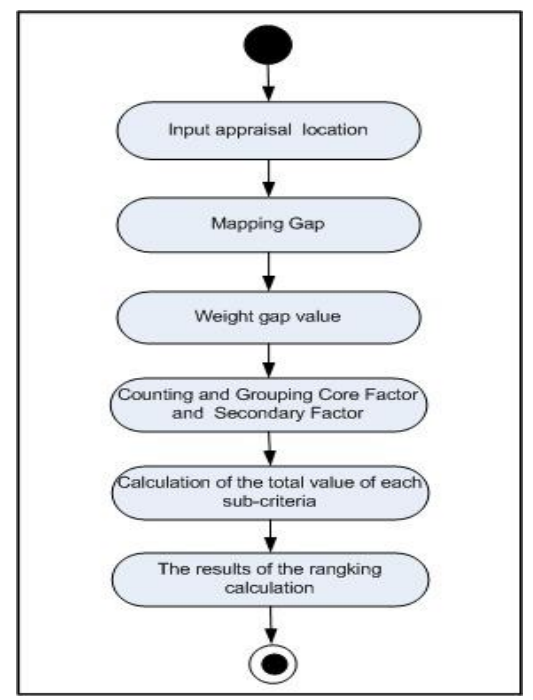

Source : (Mardiana \& Malau, 2020)

Figure 3. The flow of Determining The Franchise Location

\section{Implementation}

In this decision support system, the franchisee enters the profile of an alternative location and determines the right location to set up the franchise. The development of this decision support system uses the PHP programming language and MySQL database. Franchisee input data aspects, criteria, alternative franchise locations. Apart from that, he also entered an assessment for each alternative franchise location and hit the "proceed to calculate" button as shown in Figure 4.

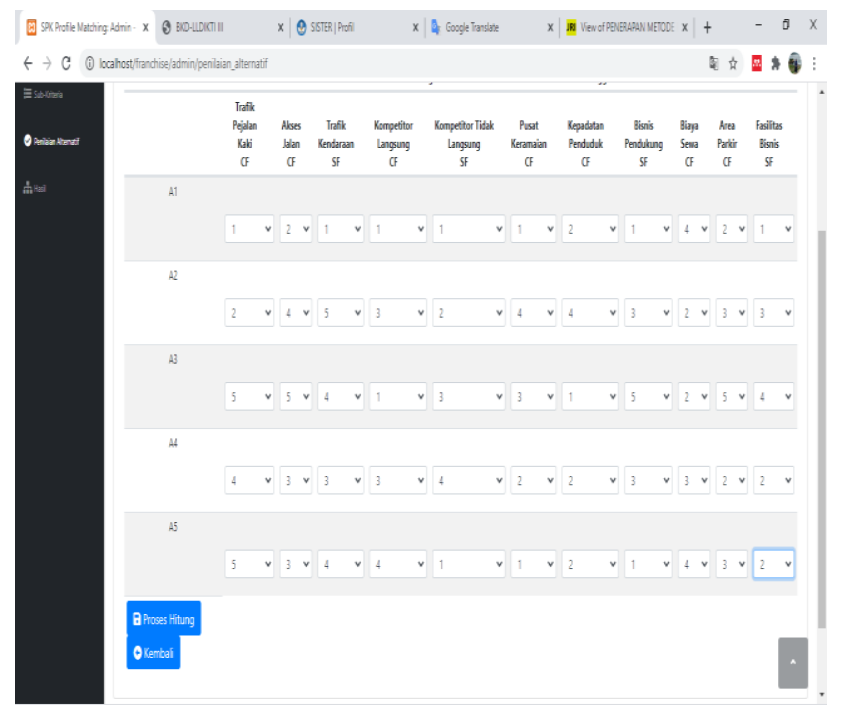

Source : (Mardiana \& Malau, 2020)

Figure 4 Evaluation of Franchise Location Alternatives

The decision support system displays the results of the profile matching method calculation process to determine the franchise location. Figure 5 typically describes the gap value between the alternative profile of the franchise location and the profile of the location expected by the franchisor.

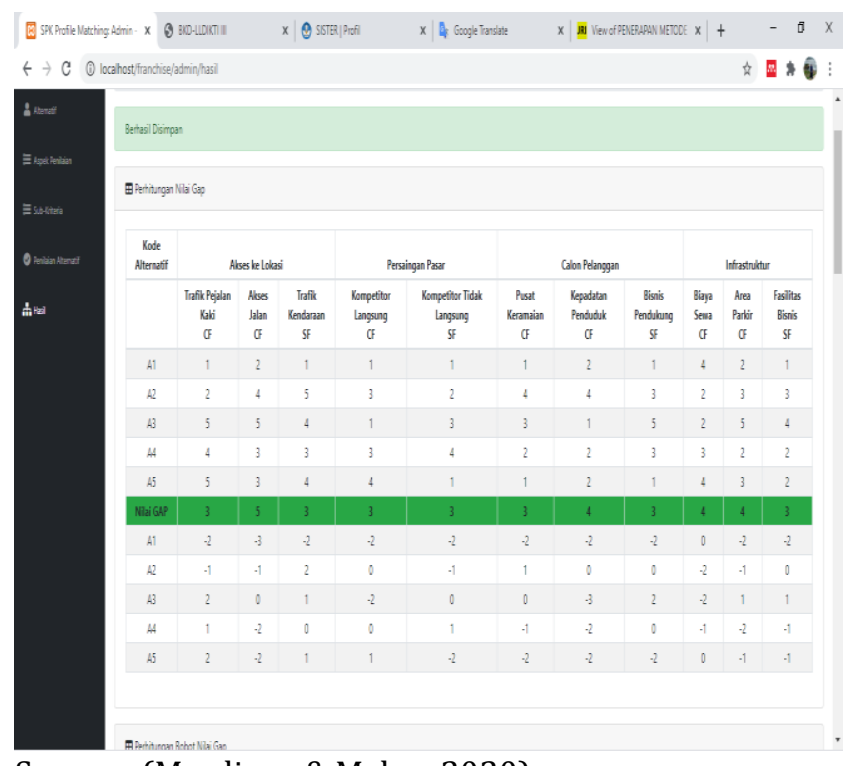

Source : (Mardiana \& Malau, 2020)

Figure 5 Mapping Gap 
After obtaining the gap value, determine the weight of the gap value for each criterion according to the gap weight value table. The results of weighting the gap values for each criterion are shown in Figure 6.

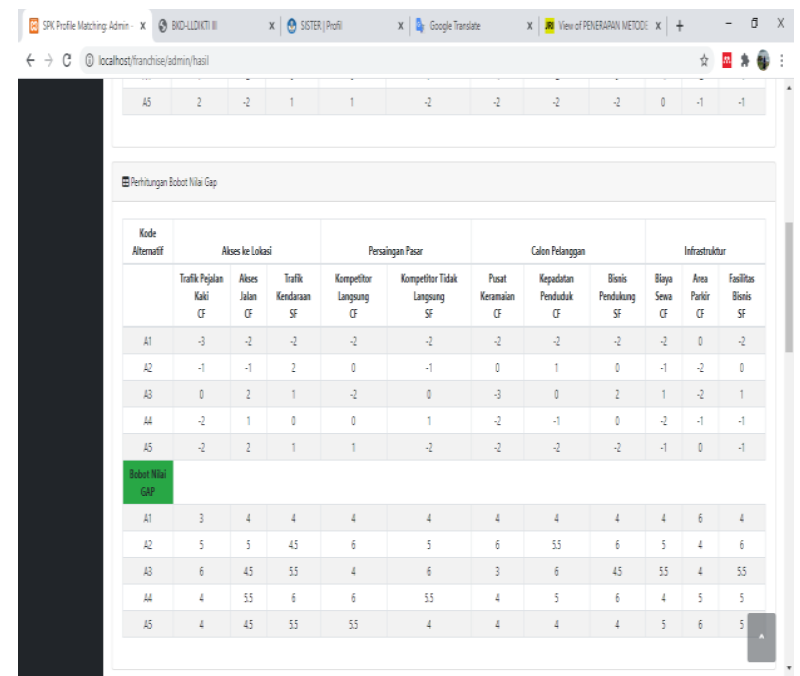

Source : (Mardiana \& Malau, 2020)

Figure 6 Weight Value Gap

The following proses classifies and calculates the average value of the core and secondary factors. Figure 7 describes the average scores of the core and secondary factors of each criterion.

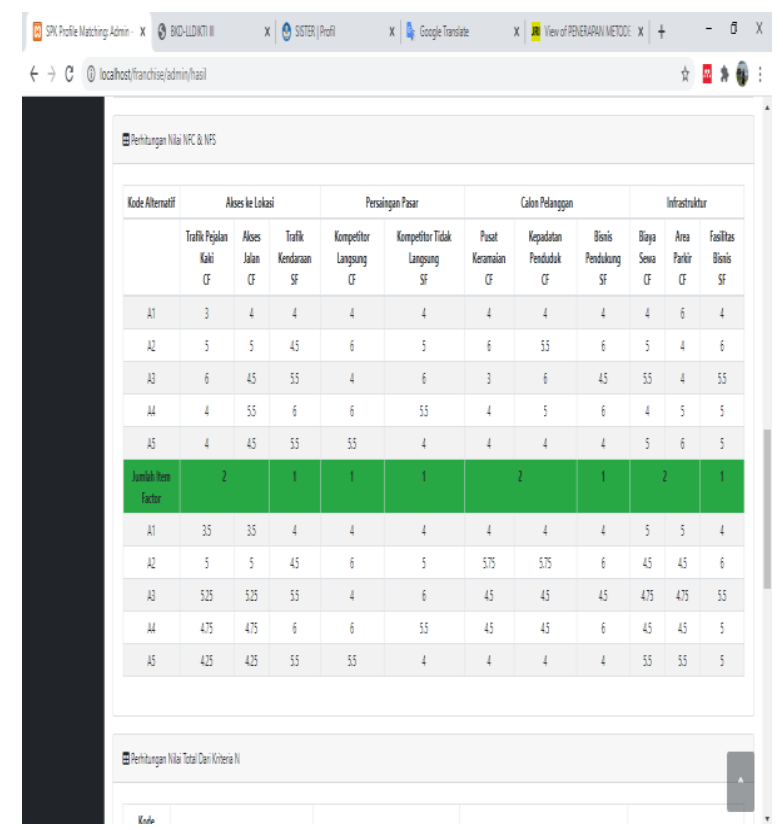

Source : (Mardiana \& Malau, 2020)

Figure 7 NCF and NSF values

Furthermore, calculate the total value of the percentage of core factors and secondary factors that affect the results of determining the franchise location. Figure 8 describes the results of the calculation of the total value of the percentage of core factors and secondary factors that affect the results of determining the franchise location.

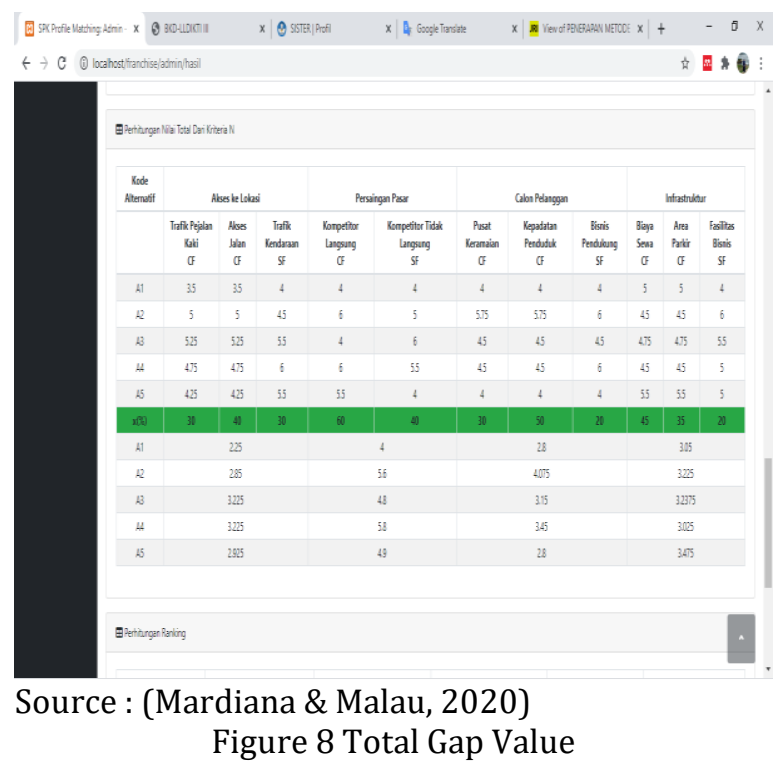

Calculate the finished result of the percentage of each aspect and sort the final score from largest to smallest value to achieve a ranking of each alternative franchise location. The decision support system provides similar franchise location recommendations to the profile of an ideal franchise location. Figure 9 describes the ranking of franchise locations based on the results of calculations using the profile matching method.

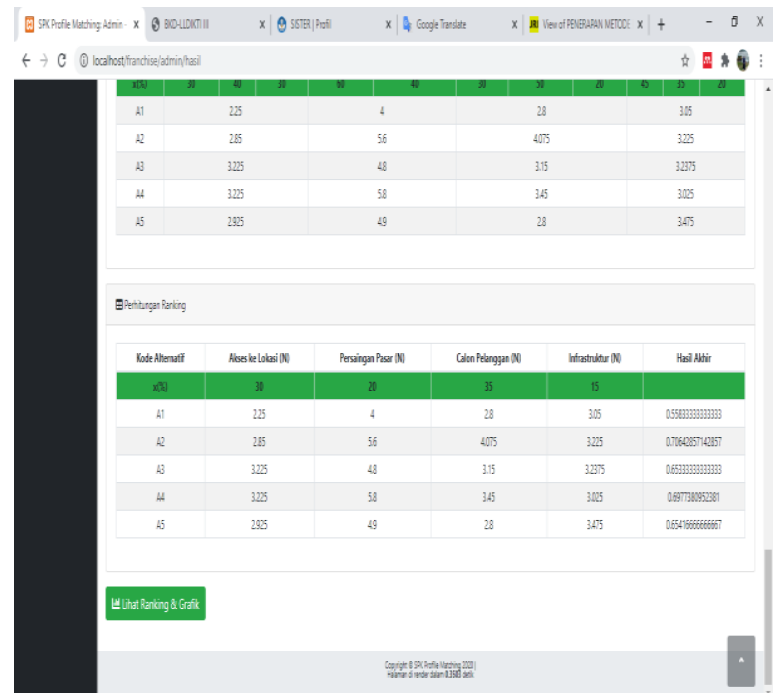

Source : (Mardiana \& Malau, 2020)

Figure 9 Results of The Alternative Franchise Location Ranking Process 


\section{Evaluation}

We tested the decision support system for determining the franchise location according to the prepared test scenarios. The results of the functionality test show that the features in the decision support system for determining the franchise location are by the functional requirements and accurately provide the right franchise location recommendations.

\section{CONCLUSION AND SUGGESTION}

In this study, a decision support system has been built using the profile matching method to determine the right franchise location. The test results show that this decision support system meets the functional and performance requirements of the system. This decision support system helps people in Indonesia to determine the location of the franchise. Furthermore, we will compare data mining methods that have the best accuracy for the classification of the feasibility of franchise locations and develop a decision support system to use to determine the location of the franchise.

\section{REFERENCE}

Danang, \& Nisar, M. F. (2017). Sistem Pendukung Keputusan Pemilihan PTS Jurusan Komputer Menggunakan Metode AHP di Kota Semarang. Simetris, 8(1), 45-52.

Dhammayanti, K., Wicaksana, A., \& Hansun, S. (2019). Position placement DSS using profile matching and analytical hierarchy process. International Journal of Scientific and Technology Research, 8(11), 204-207.

Efendi, Z. (2019). Sistem Pendukung Keputusan Pemilihan Lokasi Perumahan Menggunakan Metode Profile Matching. Jurteksi (Jurnal Teknologi Dan Sistem Informasi), VI(1).

Febrianty, \& Fatmariani. (2018). e-WaUKM Sebagai Sarana Mengembangkan Usaha Waralaba Versi Grup UKM. Prosiding Seminar
Nasional I Hasil Litbangyasa Industri Palembang, 128-136.

Fu'ad, E. N. (2015). Pengaruh Pemilihan Lokasi Terhadap Kesuksesan Usaha Berskala Mikro/Kecil Di Komplek Shopping Centre Jepara. Fakultas Ekonomi Dan Bisnis, Universitas Islam Nahdlatul Ulama Jepara, Vol. $\quad 30 \quad$ No(1), 56-67. https://doi.org/10.1016/j.foodqual.2012.04. 002

Imanuwelita, V., Putri, R. R. M., \& Amalia, F. (2018). Penentuan Kelayakan Lokasi Usaha Franchise Menggunakan Metode AHP dan VIKOR. Jurnal Pengembangan Teknologi Informasi Dan Ilmu Komputer, 2(1), 122-132.

Khumaidi, A. (2016). Penerapan Case-Based Reasoning dan Algortima Nearest Neighbor Untuk Penentuan Lokasi Waralaba. Prosiding Annual Research Seminar 2016, 2(1), 45-51. Retrieved from http://ars.ilkom.unsri.ac.id

Mardiana, T., \& Malau, Y. (2020). Research Report On Decision Support Systems To Determine The Appropriate Location of Franchises Using Profile Matching Methods. Jakarta.

P, N. E., Sihwi, S. W., \& Anggraningsih, R. (2014). Sistem Penunjang Keputusan Untuk Menentukan Lokasi Usaha Dengan Metode Simple Additive Weighting ( SAW). Jurnal ITSMArRT, 3(1), 41-46.

Verdian, A., \& Wantoro, A. (2019). Komparasi Metode Profile Matching Dengan Fuzzy Profile Matching Pada Pemilihan Wakil Kepala Sekolah. Jurnal Ilmiah Media Sisfo, 13(2),

97. https://doi.org/10.33998/mediasisfo.2019.1 3.2 .652

Welda, Kusuma, A. S., \& Mubaraq, S. (2017). Sistem Pendukung Keputusan Penentuan Kelayakan Lokasi Franchise Pada Pt . Semangat Pagi Indonesia Menggunakan. Jurnal Teknologi Informasi Dan Komputer, 3(02), 188-199. 